\title{
ERYTHROCYTE SEDIMENTATION RATE, C-REACTIVE PROTEIN DETERMINATION, SERUM PROTEIN FRACTIONS, FIBRINOGEN LEVEL AND ANTI- STREPTOLYSIN REACTION IN 52 RHEUMATIC CHILDREN
}

\author{
BY \\ N. POPOV and S. STANISHEVA \\ From the Department of Rheumatism, Second City Children's Hospital, Sofia
}

(RECEIVED FOR PUBLICATION JUNE 16, 1958)

This paper reports the results of our investigations into the clinical significance of laboratory tests in 52 cases of rheumatic fever treated in the Rheumatic Department of the Second City Children's Hospital, Sofia. The diagnosis of active rheumatic infection is based on the history, presence of carditis (in 48 cases), changes in the electrocardiograms, and by the supporting evidence of five laboratory tests: namely the erythrocyte sedimentation rate, C-reactive protein determinations, serum protein fractions, the blood fibrinogen level and the antistreptolysin-O reaction.

Eighteen of the children were in their first attack, and 34 had had one or more attacks of rheumatic fever. Thirteen cases in first attacks and 19 cases in subsequent attacks received steroid therapy.

Five children were 6 years old or under, 36 were between 7 and 11 years, and 11 were 12 or 13 years of age.

\section{Methods}

The laboratory tests were carried out by the following methods:

1. Erythrocyte Sedimentation Rate (E.S.R.). By Westergren's method (1921, 1957), estimations up to $10 \mathrm{~mm}$. in the first hour being accepted as normal.

2. C-reactive Protein (C.R.P.). Determined by the method of Anderson and McCarty (1950), using C.R.P. anti-serum produced by Schiffelin and Co., New York, and assessed as,,-+++ or +++ , in accordance with the criteria suggested by Wurhmann and Wunderly (1957).

3. Serum Protein Fractions (S.P.F.). By paper electrophoresis following Flynn and de Mayo (1951). Figures for each fraction expressed as percentage of the total protein, and the following figures accepted as pathological: albumen under $47 \%, \alpha_{1}$ globulin over $5 \%, \alpha_{2}$ globulin over $12 \%, \beta$ globulin over $14 \%$, and $\gamma$ globulin over $20 \%$ (Popov, 1956a, b). In the present paper the determinations for total protein are not discussed since deviations from the normal were slight and indeterminate.

4. Plasma Fibrinogen Level. By kjeldahlometric determination, normal range was $180-350 \mathrm{mg}$. per $100 \mathrm{ml}$. in accordance with our own findings (Popov and Stanisheva, 1958).

5. Antistreptolysin Reaction (A.S.O.). By the method described by Kalbak (1947). Standard serum from the State Serum Institute, Copenhagen, was used. Though a titre of over 200 was accepted as pathologically increased, we have previously shown (Popov and Bojadzieva, 1957) that serial estimations have a very much greater value than a single initial estimation.

In all a total of 1,743 estimations were carried out on the 52 children as follows:

$\begin{array}{llll}\text { E.S.R. } & & 527 \text { estimations } \\ \text { C.R.P., S.P.F. and A.S.O. } & \ldots & 304 \text { estimations each } \\ \text { Plasma fibrinogen } & \ldots & \ldots & 304 \text { estimations }\end{array}$

\section{Results}

Table 2 presents the results obtained for the five investigations on the 52 children, divided firstly into those in a first attack and those in subsequent attacks, and also divided according to whether hormone therapy was given or withheld. With each estimation the highest figure obtained during the active phase of the infection is given. Consequently for the E.S.R., C.R.P. and the fibrinogen levels, the results are obtained mainly at the beginning of the illness. For the A.S.O. the results obtained are usually in the middle of an attack, whilst the figures for the S.P.F. were obtained at various times throughout the attack.

Consideration of these results reveals the following points:

1. Erythrocyte Sedimentation Rate. The E.S.R. remained normal in seven children, of whom only one was in a first attack. Very high figures were obtained in 18 children, 10 in their first attack. 
TABLE 2

\begin{tabular}{|c|c|c|c|c|c|c|c|c|c|c|c|c|c|c|c|c|c|c|c|}
\hline & \multirow{3}{*}{ No. } & \multicolumn{4}{|c|}{$\begin{array}{l}\text { E.S.R. } \\
\text { (mm./1st hr.) }\end{array}$} & \multicolumn{4}{|c|}{ C.R.P. } & \multicolumn{4}{|c|}{ S.P.F. } & \multicolumn{3}{|c|}{$\begin{array}{c}\text { Fibrinogen } \\
\text { Level (mg. \%) }\end{array}$} & \multicolumn{3}{|c|}{ A.S.O. (units) } \\
\hline & & \multirow[b]{2}{*}{$>10$} & \multirow{2}{*}{$\begin{array}{l}11 \\
\text { to } \\
30\end{array}$} & \multirow{2}{*}{$\begin{array}{l}31 \\
\text { to } \\
60\end{array}$} & \multirow[b]{2}{*}{$\begin{array}{c}\text { Over } \\
60\end{array}$} & \multirow[b]{2}{*}{-} & \multirow[b]{2}{*}{+} & \multirow[b]{2}{*}{++} & \multirow[b]{2}{*}{+++} & \multirow[b]{2}{*}{ Normal } & \multicolumn{3}{|c|}{ Increased } & \multirow{2}{*}{$\begin{array}{c}180 \\
\text { to } \\
350\end{array}$} & \multirow{2}{*}{$\begin{array}{c}360 \\
\text { to } \\
550\end{array}$} & \multirow[b]{2}{*}{$\begin{array}{l}\text { over } \\
550\end{array}$} & \multirow[b]{2}{*}{$\underset{200}{\text { under }}$} & \multirow{2}{*}{$\begin{array}{c}300 \\
\text { to } \\
600\end{array}$} & \multirow{2}{*}{$\begin{array}{l}800 \\
\text { and } \\
\text { over }\end{array}$} \\
\hline & & & & & & & & & & & $\alpha_{1}$ & $\begin{array}{l}\alpha_{2} \\
\gamma\end{array}$ & $\begin{array}{c}\gamma \\
\text { only }\end{array}$ & & & & & & \\
\hline $\begin{array}{l}\text { I. First attack (18) } \\
\text { (a) with steroid therapy }\end{array}$ & 13 & - & 2 & 2 & 9 & 1 & - & 4 & 8 & 1 & 8 & 4 & 一 & 5 & 3 & 5 & 1 & 5 & 7 \\
\hline (b) without steroid therapy & 5 & 1 & 1 & 2 & 1 & - & 2 & - & 3 & - & 4 & 1 & - & 2 & 3 & - & - & 2 & 3 \\
\hline $\begin{array}{l}\text { II. Subsequent Attacks (34) } \\
\text { (a) with steroid therapy }\end{array}$ & 19 & 2 & 5 & 6 & 6 & - & 2 & 10 & 7 & - & 9 & 7 & 3 & 10 & 6 & 3 & 3 & 7 & 9 \\
\hline (b) without steroid therapy & 15 & 4 & 4 & 5 & 2 & 4 & 7 & 1 & 3 & 4 & 1 & 5 & 5 & 12 & 2 & 1 & 8 & 5 & 2 \\
\hline Totals & 52 & 7 & 12 & 15 & 18 & 5 & 11 & 15 & 21 & 5 & 22 & 17 & 8 & 29 & 14 & 9 & 12 & 19 & 21 \\
\hline
\end{tabular}

The follow up of the E.S.R. showed that in the children in their first attack and receiving steroids it remained raised for an average of 25 days, whilst in three of these the E.S.R. was not normal until the thirtieth day, and in another not until the forty-fifth day. Of the five children in their first attack not given steroid therapy, in one the E.S.R. was normal, in two it became normal in about 20 days, whilst in the remaining two, both of whom suffered from tonsillitis during their rheumatic infection, the E.S.R. remained raised for 60 days.

Of the children in a subsequent attack and receiving steroid therapy, 11 showed a raised E.S.R. for an average of 50 days (in two children for 65 days, in one child for about three months); of the children in a subsequent attack and not receiving steroid therapy the E.S.R. became normal also on an average in about 50 days (in two children after two months and in one after three months).

2. C.R.P. In general the C.R.P. tests showed positive or negative results much in accordance with the data quoted in the literature (Müller, 1956), but in many cases variations in the intensity of the reaction were obtained especially from + to ++ during the course of the disease. Of 18 children in the first attack 11 showed a raised C.R.P., usually ++ . In one child the estimation was persistently negative in spite of clinical evidence of active infection, whilst in six children estimations varied from + to ++ from time to time.

Of 35 children with subsequent attacks, in 10 the C.R.P. was +++ steadily over a long period, in four it was constantly negative. Of the eight children in the first attack and being treated with hormones, C.R.P. tests in seven steadily improved from the onset of the disease, and in one (a protracted case with several previous attacks) the C.R.P. remained positive for about three months as did the E.S.R. and S.P.F. In general this test was usually the first to appear positive and the first to become negative with the exception of the fibrinogen level which was often the first to become negative in children with a first attack receiving steroid therapy.

3. S.P.F. Protein fractions are related to the humeral changes in the connective tissue during the different phases in rheumatic progress (Chaptal, Jean, Campo, Alram and Fraisse, 1954). In the present series also the dysproteinaemia was present at the beginning of the attack and its intensity appeared to correspond to the degree of the exudative and productive tissue changes. Moreover, the dysproteinaemia remained raised for a long time after the E.S.R. and S.R.P. had become negative. These findings are in accordance with those of Jacox (1956).

In the present series, five children showed repeatedly normal values in spite of other evidence of activity, four of whom were in subsequent attacks and not receiving steroid therapy. In the remaining 47 dysproteinaemia was marked at the beginning of the attack. In 22, there was at the beginning of the attack an increased $\alpha_{1}$ and $\alpha_{2}$ globulin with a moderately increased $\gamma$ globulin. As the process evolved the $\alpha$ globulin fractions decreased and the $\gamma$ globulin fraction increased up to a figure of $30 \%$. In this group the dysproteinaemia lasted for an average of 55 days. By contrast, of the 17 children in their first attack, though there was a similar pattern for the $\alpha_{2}$ and the $\gamma$ fractions, the dysproteinaemia lasted on an average about 40 days. In two children who had an intercurrent infection of measles $\gamma$ globulin dropped to 10 and $12 \%$ respectively.

We agree with the data of Payne and Forsyth (1958) that children over the age of six years have approximately adult protein fraction levels. We also agree with Klaishevitsch (1958) regarding the behaviour of the globulin fractions in the cardiac forms of rheumatism and that in a first attack 
great deviations from the normal are observed, also a more rapid return to normal compared with children in subsequent attacks.

4. Fibrinogen Levels. We previously studied these in 70 children (Popov and Stanisheva, 1958). It was there concluded that during the first attack without complications and also in many repeated attacks the fibrinogen level may become normal during the first week of the disease, but that if the condition becomes protracted, and particularly in repeated attacks, the fibrinogen level remains high for a long time. In the present series, in 29 children fibrinogen levels were normal, between 180 and $350 \mathrm{mg}$. $\%$; of 23 children with high fibrinogen levels, and in three cases with previous attacks and receiving hormone treatment the fibrinogen levels remained high for 30,40 and 60 days respectively. In the remaining cases there was a greatly raised fibrinogen level, from 360 to $850 \mathrm{mg}$. \%, which became normal during the first 10 days.

5. A.S.O. Twelve of our children had a titre constantly under 200 units, i.e. within the upper limit of normal, and 11 of these had had previous attacks. In 19 the A.S.O. titre was between 300 and 600 units; seven of these were in their first attack, and 12 had had previous attacks. In 21 patients the A.S.O. titre was between 800 and 1,600 and 10 of these were in their first attack. In children with a raised A.S.O. titre the height of the curve was reached about the end of the second week, whilst in those treated with cortisone the high level was sustained for from 30 to 75 days. Two children were exceptional in that the A.S.O. fell before the twentieth day. Chaptal et al. (1954) and Harris, Needleman, Harris and Friedman (1956) and Lanza, Morbidelli and Papotti (1956) reported that a quick fall of the A.S.O. was brought about by steroid therapy. There were three such cases in our series receiving steroids. In general, in children with previous attacks and treated with steroids the A.S.O. level remained high for $\mathbf{4 0}$ days.

In eight patients there was a very high level of A.S.O. titre at the beginning of their admission to hospital. In these children there was a history suggesting that they had been admitted during the second or third week of their illness.

In nine children receiving steroid therapy, three of whom were in their first attack, when steroid therapy was discontinued or diminished there was a simultaneous increase of the E.S.R., C.R.P., S.P.F., and some tendency to elevation of the A.S.O., as also clinical deterioration of the cardiac condition. This rebound phenomenon is in accordance with the findings of Holt (1956).

An effort was made to correlate the laboratory findings of the cases given steroids with the following results: 23 cases showed a correlation between the five tests, in nine cases, a correlation between the E.S.R., C.R.P., S.P.F. and the A.S.O.; in 10 cases between the E.S.R., the C.R.P., and the S.P.F.; in four cases between the C.R.P., the S.P.F. and the A.S.O., and in three cases between the C.R.P. and the A.S.O. Completely normal laboratory findings in the presence of clinical evidence of activity was observed in three cases.

\section{Summary}

At intervals of seven to 10 days 1,743 investigations for E.S.R., C.R.P., S.P.F. and fibrinogen levels and A.S.O. titre were performed in 52 rheumatic children with active infection. Eighteen of these children were in their first attack, of whom 13 were being treated with steroid therapy, and 34 had had previous attacks, 19 of whom were receiving steroids.

In 23 cases there was good correlation between the positive findings in the five tests when related to clinical activity. In three cases the laboratory tests were normal in the face of evidence of clinical activity. In the remaining cases there was correlation between four tests in nine cases, between three tests in 14 cases, between two tests in three cases. There was a rebound phenomenon in nine cases.

\section{REFERENCES}

Anderson, H. C. and McCarty, M. (1950). Amer. J. Med., 8, 445 Chaptal, J., Jean, R., Campo, C., Alram, D. and Fraisse, J. (1954). Arch. franc. Pédiat., 11, 1055

Flynn, F. V. and Mayo, P. de (1951). Lancet, 2, 235

Harris, T. N., Needleman, H. L., Harris, S. and Friedman, S. (1956) Pediatrics, 17, 29

Holt, K. S. (1956). Arch. Dis. Childh., 31, 444.

Jacox, R. F. (1956). N.Y. St.J. Med., 56, 672: (cf. Abstr. Wld Med. (1956). 20, 215.)

Kalbak, K. (1947). The Antistreptolysin Reaction. State Serum Institute, Copenhagen.

Klaishevitsch, G. I. (1958). Pediatrija, no. 1, p. 68.

Lanza, I., Morbidelli, R. and Papotti, G. (1956). Minerva med. (Torino), (parte Sci), 47 (1), 553.

Müller, W. (1956). Z. Rheumaforsch., 15, 31.

Payne, W. W. and Forsyth, C. C. (1958). Arch Dis. Childh., 33, 61 Payne, W. W. and Forsyth, C. C. (1958).
Popov, N. (1956a). Sovr. Med., 7, 116.

Poporitic (1956). Scientific Works of the State Institute for Haematology and Blood Transfusion in Sofia, 3, 64.

and Bojadzieva, M. (1957). Sovr. Med., 8, 33.

- and Stanisheva, S. (1958). Pediat. Akuš. Ginec., 2, 29.

Westergren, A. (1921). Acta med. scand., 54, 247.

(1957). Triangle, 3, 20.

Wuhrmann, F. and Wunderly, C. (1957). Die Bluteiweisskörper des Menschen, 3rd ed. Basel. 